\title{
Two-stage culture procedure using thidiazuron for efficient micropropagation of Stevia rebaudiana, an anti-diabetic medicinal herb
}

\author{
Pallavi Singh $\cdot$ Padmanabh Dwivedi
}

Received: 21 June 2013/Accepted: 11 September 2013/Published online: 26 September 2013

(C) The Author(s) 2013. This article is published with open access at Springerlink.com

\begin{abstract}
Stevia rebaudiana Bertoni, member of Asteraceae family, has bio-active compounds stevioside and rebaudioside which taste about 300 times sweeter than sucrose. It regulates blood sugar, prevents hypertension and tooth decay as well as used in treatment of skin disorders having high medicinal values, and hence there is a need for generating the plant on large scale. We have developed an efficient micropropagation protocol on half strength $\mathrm{Mu}$ rashige and Skoog (MS) media, using two-stage culture procedures. Varying concentrations of cytokinins, i.e., benzylaminopurine, kinetin and thidiazuron (TDZ) were supplemented in the nutrient media to observe their effects on shoot development. All the cytokinins promoted shoot formation, however, best response was observed in the TDZ $(0.5 \mathrm{mg} / \mathrm{l})$. The shoots from selected induction medium were sub-cultured on the multiplication media. The media containing $0.01 \mathrm{mg} / \mathrm{l} \mathrm{TDZ}$ produced maximum number of shoot $(11.00 \pm 0.40)$ with longer shoots $(7.17 \pm 0.16)$ and highest number of leaves $(61.00 \pm 1.29)$. Rooting response was best observed in one-fourth strength on MS media supplemented with indole-3-butyric acid $(1.0 \mathrm{mg} / \mathrm{l})$ and activated charcoal $(50 \mathrm{mg} / \mathrm{l})$ with $(11.00 \pm 0.40)$ number of roots. The plantlets thus obtained were hardened and transferred to the pots with soil and sand mixture, where the survival rate was $80 \%$ after 2 months. Quantitative analysis of stevioside content in leaves of in vivo mother plant and in vitro plantlets was carried out by high performance liquid chromatography. A remarkable increase in stevioside content was noticed in the in vitro-raised plants as
\end{abstract}

P. Singh · P. Dwivedi $(\bowtie)$

Laboratory of Plant Tissue Culture and Stress Physiology,

Department of Plant Physiology, Institute of Agricultural

Sciences, Banaras Hindu University, Varanasi, India

e-mail: pdwivedi25@rediffmail.com compared to in vivo grown plants. The protocol reported here might be useful in genetic improvement and high stevioside production.

Keywords Micropropagation - Murashige and Skoog medium $\cdot$ Stevia rebaudiana $\cdot$ Stevioside $\cdot$ Thidiazuron

$\begin{array}{ll}\text { Abbreviations } \\ \text { MS } & \text { Murashige and Skoog } \\ \text { BAP } & \text { Benzylaminopurine } \\ \text { Kn } & \text { Kinetin } \\ \text { TDZ } & \text { Thidiazuron } \\ \text { IBA } & \text { Indole-3-butyricacid } \\ \text { HPLC } & \text { High performance liquid chromatography }\end{array}$

\section{Introduction}

Stevia rebaudiana Bertoni, a member of Asteraceae family, native to certain regions of South America-Brazil and Paraguay (Alhady 2011), is one of the important antidiabetic medicinal herbs. It is indigenous to the Rio Monday Valley of the Amambay mountain region at altitudes between 200 and $500 \mathrm{~m}$ (Pande and Gupta 2013). The compounds in its leaves, stevioside and rebaudioside taste about 300 times sweeter than sucrose (Geuns 2003). It is used as sweetening agent and has enormous commercial importance. Its other medicinal uses include regulating blood sugar, preventing hypertension and tooth decay, and treatment of skin disorders (Singh and Rao 2005). Stevia also has healing effect on blemishes, wound cuts and scratches, besides being helpful in weight and blood pressure management. Conventional propagation in

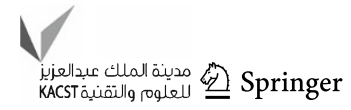


this plant is restricted due to the poor seed viability coupled with very low germination rate. Role of vegetative propagation method is also limited as specific habitat conditions are mandatory to grow the plants in addition to low acclimatization rate in soil. A suitable alternative method to prepare sufficient amount of plants within short time duration is the use of in vitro cultures. There are reports of in vitro clonal propagation of Stevia using nodal segments (Sivaram and Mukundan 2003; Mitra and Pal 2007; Singh et al. 2012). In vitro clonal propagation of Stevia has been carried out using nodal, inter-nodal segment (Uddin et al. 2006; Ahmed et al. 2007; Sairkar et al. 2009; Thiyagarajan and Venkatachalam 2012), leaf (Ali et al. 2010) and shoot-tip explants (Anbazhagan et al. 2010; Das et al. 2011). The present study was undertaken to evaluate the effectiveness of two-stage culture procedures as means of micropropagation of $S$. rebaudiana in half strength MS media, which has not been attempted before, using various cytokinins-benzylaminopurine (BAP), kinetin ( $\mathrm{Kn})$ and thidiazuron (TDZ). The study also compares the stevioside content in the in vivo and in vitro leaves, supporting the effectiveness of micropropagation protocol generated.

\section{Materials and methods}

\section{Explant source}

Healthy plants of $S$. rebaudiana were collected from local herbal nurseries and established in horticulture garden of BHU campus. Nodal explants $(1.5-2.0 \mathrm{~cm}$ long and $0.2-0.4 \mathrm{~cm}$ thick) were washed thoroughly for $15 \mathrm{~min}$ under running tap water, treated with Tween 80 (2-3 drops in $100 \mathrm{ml}$ ) for $7 \mathrm{~min}$ followed by treatment with $0.002 \%$ $(\mathrm{w} / \mathrm{v})$ bavistin for 2-3 min. These were surface sterilized with $0.1 \%$ (w/v) $\mathrm{HgCl}_{2}$ for 2-3 min and washed 4-5 times with sterile double distilled water.

Shoot induction media

Murashige and Skoog medium (1962) (half strength) was used supplemented with $3 \%(\mathrm{w} / \mathrm{v})$ sucrose, ascorbic acid $(50 \mathrm{mg} / \mathrm{l})$, gibberellic acid $(1 \mathrm{mg} / \mathrm{l})$, solidified with $0.8 \%$ (w/v) agar; $\mathrm{pH}$ was adjusted to 5.8 prior to autoclaving at $121{ }^{\circ} \mathrm{C}$ for $20 \mathrm{~min}$. The nodal explants were inoculated with different concentrations of TDZ $(0.01,0.03,0.05$, $0.1,0.2,0.5 \mathrm{mg} / \mathrm{l}), \operatorname{BAP}(0.2,0.5,1.0 \mathrm{mg} / \mathrm{l})$ and $\mathrm{Kn}(0.2$, $0.5,1.0 \mathrm{mg} / \mathrm{l})$ to observe their effect on shoot development and multiplication. The cultures were kept under cool, fluorescent light ( $16 \mathrm{~h}$ photoperiod) at $25 \pm 2{ }^{\circ} \mathrm{C}$ in the culture room. Data were noted after 3 weeks of inoculation.
Multiplication media

Shoots (3-week-old) obtained from the shoot induction media containing $0.2 \mathrm{mg} / 1 \mathrm{BAP}(\mathrm{B}), 0.2 \mathrm{mg} / \mathrm{l} \mathrm{Kn}(\mathrm{E})$, $0.2 \mathrm{mg} / \mathrm{l}$ each of BAP and $\mathrm{Kn}(\mathrm{H}), 0.5 \mathrm{mg} / \mathrm{l} \mathrm{TDZ}(\mathrm{P})$, as shown in Table 1, were sub-cultured on multiplication media. The multiplication medium consisted of half MS supplemented with TDZ $(0.01 \mathrm{mg} / \mathrm{l})$; half MS devoid of any growth regulator and original shoot induction medium (B, E, H and P), as shown in Table 2; cultures without growth regulators served as control. Total number of shoots, length of shoots and number of leaves were observed after 4 weeks of culture.

In vitro root induction

The elongated shoots with length more than $5.0 \mathrm{~cm}$ were excised from the culture flasks and transferred to the rooting media amended with $0.2,0.5$ and $1.0 \mathrm{mg} / \mathrm{l} \mathrm{IBA}$ under aseptic condition. The growth regulator was added separately to half strength and one-fourth strength MS media containing $3 \%$ sucrose to determine the effect of MS salt concentration on root induction (Table 3). The media was additionally supplemented with activated charcoal $(50 \mathrm{mg} / \mathrm{l})$, ascorbic acid $(50 \mathrm{mg} / \mathrm{l})$, polyvinylpolypyrrolidone $(100 \mathrm{mg} / \mathrm{l})$ and gibberellic acid $(0.5 \mathrm{mg} / \mathrm{l})$. Total number of roots per shoot as well as length of the roots was measured after 4 weeks of culture.

\section{Hardening}

Rooted plants were carefully removed from the culture flasks, washed with sterile water to remove agar media, placed in the plastic cups filled with sterilized perlite. The plants were covered with polythene bags to maintain high humidity. These plants were maintained in the culture room for 3 weeks with the following atmospheric conditions: temperature, $25 \pm 2{ }^{\circ} \mathrm{C}$; light, $16 \mathrm{~h}$ photoperiod. Afterwards these were transferred to pots containing sterilized garden soil and sand (1:1).

\section{Observation recorded and statistical analysis}

Observations were recorded and different parameters (number of shoots, length of shoots and number of leaves) were examined using 8-10 replicates. Data were subjected to Duncan's multiple range test (Duncan 1955).

Stevioside analysis

Biochemical analysis of the in vivo and in vitro-raised plants was performed using more sensitive and rapid method of HPLC (Shimadzu, Japan) analysis to confirm the 
presence of stevioside in leaves. Stevioside standard was obtained from Sigma Ltd., USA (95\% purity).

Conditions for HPLC study: column used C-18, mobile phase used methanol:water (80:20) with the flow rate of $1.5 \mathrm{ml} / \mathrm{min}$ (injection $10 \mu \mathrm{l}$ ). Peak detection was made at $210 \mathrm{~nm}$ at the room temp of $25^{\circ} \mathrm{C}$.

Standard preparation: $1 \mathrm{mg}$ of stevioside sample was dissolved in $10 \mathrm{ml}$ of methanol. Then $10 \mu \mathrm{l}$ was applied to HPLC chromatogram.

Sample preparation from Stevia leaves: Stevia leaves were dried at $50{ }^{\circ} \mathrm{C}$ for $24 \mathrm{~h}$ in dark and pulverized to uniform size. This material ( $2 \mathrm{~g}$ ) was extracted in boiling water $(2 \times 50 \mathrm{ml})$ and further boiled for $30 \mathrm{~s}$. Cooled extract was first filtered through the filter paper and then microfiltered $(0.45 \mu \mathrm{m})$ before it was ready for analysis.

Calculation of percentage of stevioside $(X)$ in the sample was done as per the formula*:

$\% X=[\mathrm{WS} / W] \times[\mathrm{f} X \times \mathrm{A} X / \mathrm{AS}] \times 100$

where, WS is the amount (mg) of stevioside in the standard solution $W$ is the amount (mg) of sample in the sample solution AS is the peak area for stevioside from the standard solution $\mathrm{A} X$ is the peak area of $X$ for the sample solution $\mathrm{f} X$ is the ratio of the formula weight of $X$ to the formula weight of stevioside: 1.00 (stevioside).

Prepared at the 68th Joint FAO/WHO Expert Committee on Food Additives JECFA (2007).

\section{Results and discussion}

Shoot induction

The nodal explants were inoculated in half strength MS media with various concentration of BAP $(0.2,0.5,1.0 \mathrm{mg} /$ 1). Almost at every concentration, bud break was seen during 3-7 days after inoculation. The parameters recorded (number of shoots, length of shoot and number of leaves) have shown differences at various concentrations in the induction media. $0.2 \mathrm{mg} / \mathrm{l}$ BAP showed better growth in terms of number of shoots $(2.25 \pm 0.25)$, shoot length $(1.20 \pm 0.27 \mathrm{~cm})$, number of leaves $(15.75 \pm 1.84)$. Multiple shoot observed from 1.0 to $2.0 \mathrm{mg} / \mathrm{l} \mathrm{BAP} \mathrm{(MS} \mathrm{media)}$ and maximum response as well as healthy shoot was noticed at $1 \mathrm{mg} / \mathrm{l} \mathrm{BAP}$ (Ranganathan 2012). When kinetin was used, $0.2 \mathrm{mg} / \mathrm{l}$ showed better response in terms of all the parameters; number of shoots $(2.00 \pm 0.00)$, shoot length $(1.95 \pm 0.35 \mathrm{~cm})$, though media with $0.5 \mathrm{mg} / 1$ of kinetin has shown higher number of leaves $(20.00 \pm 0.81)$. BAP and Kinetin at different concentrations $(0.2,0.5,1.0 \mathrm{mg} / \mathrm{l}$ of each) when applied together, produced the best response at lower concentration $(0.2 \mathrm{mg} / \mathrm{l})$, in terms of number of shoots $(2.00 \pm 0.00)$, shoot length $(3.10 \pm 0.96 \mathrm{~cm})$ and number of leaves $(11.50 \pm 0.50)$. Mehta et al. (2012) reported that best shooting response was observed on MS media containing $0.5 \mathrm{mg} / \mathrm{l} \mathrm{BAP}+2.0 \mathrm{mg} / \mathrm{l} \mathrm{Kn}$ (average number of

Table 1 Effect of various cytokinins on in vitro shoot induction in Stevia rebaudiana

\begin{tabular}{|c|c|c|c|c|c|c|}
\hline & \multicolumn{3}{|c|}{ Plant growth regulator $(\mathrm{mg} / \mathrm{l})$} & \multirow[t]{2}{*}{ Number of shoots } & \multirow[t]{2}{*}{ Shoot length $(\mathrm{cm})$} & \multirow[t]{2}{*}{ Number of leaves } \\
\hline & BAP & Kinetin & TDZ & & & \\
\hline A & 0.0 & 0.0 & 0.0 & $1.50 \pm 0.28^{\mathrm{a}}$ & $1.75 \pm 0.14^{\mathrm{bcd}}$ & $14.50 \pm 1.50^{\mathrm{bc}}$ \\
\hline B & 0.2 & - & - & $2.25 \pm 0.25^{\mathrm{a}}$ & $1.20 \pm 0.27^{\mathrm{abc}}$ & $15.75 \pm 1.84^{\mathrm{bc}}$ \\
\hline $\mathrm{C}$ & 0.5 & - & - & $1.75 \pm 0.25^{\mathrm{a}}$ & $0.80 \pm 0.08^{\mathrm{ab}}$ & $15.25 \pm 1.79^{\mathrm{bc}}$ \\
\hline $\mathrm{D}$ & 1.0 & - & - & $2.00 \pm 0.00^{\mathrm{a}}$ & $0.45 \pm 0.09^{\mathrm{a}}$ & $12.00 \pm 1.63^{\mathrm{ab}}$ \\
\hline $\mathrm{E}$ & - & 0.2 & - & $2.00 \pm 0.00^{\mathrm{a}}$ & $1.95 \pm 0.35^{\text {cde }}$ & $12.25 \pm 0.25^{\mathrm{ab}}$ \\
\hline $\mathrm{F}$ & - & 0.5 & - & $1.50 \pm 0.28^{\mathrm{a}}$ & $1.00 \pm 0.08^{\mathrm{ab}}$ & $20.00 \pm 0.81^{\mathrm{de}}$ \\
\hline G & - & 1.0 & - & $1.75 \pm 0.25^{\mathrm{a}}$ & $1.15 \pm 0.05^{\mathrm{abc}}$ & $17.50 \pm 0.50^{\mathrm{cd}}$ \\
\hline $\mathrm{H}$ & 0.2 & 0.2 & - & $2.00 \pm 0.00^{\mathrm{a}}$ & $3.10 \pm 0.96^{\mathrm{f}}$ & $11.50 \pm 0.50^{\mathrm{ab}}$ \\
\hline I & 0.5 & 0.5 & - & $2.25 \pm 0.25^{\mathrm{a}}$ & $0.82 \pm 0.19^{\mathrm{ab}}$ & $9.50 \pm 0.95^{\mathrm{a}}$ \\
\hline $\mathrm{J}$ & 1.0 & 1.0 & - & $1.75 \pm 0.25^{\mathrm{a}}$ & $0.95 \pm 0.12^{\mathrm{ab}}$ & $8.00 \pm 1.63^{\mathrm{a}}$ \\
\hline K & - & - & 0.01 & $2.00 \pm 0.00^{\mathrm{a}}$ & $2.82 \pm 0.11^{\mathrm{ef}}$ & $22.75 \pm 0.94^{\mathrm{ef}}$ \\
\hline $\mathrm{L}$ & - & - & 0.03 & $2.00 \pm 0.00^{\mathrm{a}}$ & $2.60 \pm 0.21^{\mathrm{def}}$ & $23.50 \pm 1.25^{\mathrm{ef}}$ \\
\hline M & - & - & 0.05 & $2.00 \pm 0.00^{\mathrm{a}}$ & $2.77 \pm 0.13^{\mathrm{ef}}$ & $24.25 \pm 0.47^{\mathrm{f}}$ \\
\hline $\mathrm{N}$ & - & - & 0.1 & $2.00 \pm 0.00^{\mathrm{a}}$ & $2.65 \pm 0.12^{\mathrm{def}}$ & $24.75 \pm 0.94^{\mathrm{fg}}$ \\
\hline $\mathrm{O}$ & - & - & 0.2 & $2.00 \pm 0.00^{\mathrm{a}}$ & $2.30 \pm 0.13^{\mathrm{def}}$ & $28.50 \pm 1.25^{\mathrm{g}}$ \\
\hline $\mathrm{P}$ & - & - & 0.5 & $3.00 \pm 0.57^{\mathrm{b}}$ & $2.20 \pm 0.11^{\mathrm{def}}$ & $33.00 \pm 2.88^{\mathrm{h}}$ \\
\hline
\end{tabular}

Parameters have been recorded after 3 weeks of culture. Data are in the form of mean \pm SEM, and means followed by the same letter within the columns are not significantly different $(P=0.05)$ using Duncan's multiple range test 
Table 2 Effect of cytokinins on shoot multiplication of Stevia rebaudiana

\begin{tabular}{|c|c|c|c|c|}
\hline Induction medium & Multiplication medium & Number of shoots & Shoot length $(\mathrm{cm})$ & Number of leaves \\
\hline \multirow[t]{3}{*}{ BAP $(0.2 \mathrm{mg} / \mathrm{l})$} & B & $5.75 \pm 0.25^{\mathrm{bc}}$ & $4.32 \pm 0.48^{\mathrm{a}}$ & $46.25 \pm 0.62^{\mathrm{cd}}$ \\
\hline & $1 / 2 \mathrm{MS}$ & $3.25 \pm 0.62^{\mathrm{a}}$ & $4.20 \pm 0.16^{\mathrm{a}}$ & $37.50 \pm 1.70^{\mathrm{b}}$ \\
\hline & $1 / 2 \mathrm{MS}+\mathrm{TDZ}(0.01)$ & $9.25 \pm 0.25^{\mathrm{d}}$ & $6.67 \pm 0.26^{\mathrm{d}}$ & $50.50 \pm 0.95^{\mathrm{ef}}$ \\
\hline \multirow[t]{3}{*}{$\mathrm{Kn}(0.2 \mathrm{mg} / \mathrm{l})$} & $\mathrm{E}$ & $4.75 \pm 0.25^{\mathrm{b}}$ & $5.05 \pm 0.09^{\mathrm{b}}$ & $44.75 \pm 0.48^{\mathrm{c}}$ \\
\hline & $1 / 2 \mathrm{MS}$ & $2.50 \pm 0.28^{\mathrm{a}}$ & $4.82 \pm 0.16^{\mathrm{ab}}$ & $30.50 \pm 0.95^{\mathrm{a}}$ \\
\hline & $1 / 2 \mathrm{MS}+\mathrm{TDZ}(0.01)$ & $8.50 \pm 0.28^{\mathrm{d}}$ & $6.95 \pm 0.95^{\mathrm{d}}$ & $50.00 \pm 0.81^{\mathrm{ef}}$ \\
\hline \multirow[t]{3}{*}{ BAP and $\mathrm{Kn}(0.2 \mathrm{mg} / \mathrm{l} \mathrm{each})$} & $\mathrm{H}$ & $5.25 \pm 0.25^{\mathrm{bc}}$ & $5.20 \pm 0.14^{\mathrm{b}}$ & $40.75 \pm 0.75^{\mathrm{b}}$ \\
\hline & $1 / 2 \mathrm{MS}$ & $3.00 \pm 0.40^{\mathrm{a}}$ & $5.90 \pm 0.12^{\mathrm{c}}$ & $30.50 \pm 1.70^{\mathrm{a}}$ \\
\hline & $1 / 2 \mathrm{MS}+\mathrm{TDZ}(0.01)$ & $8.75 \pm 0.25^{\mathrm{d}}$ & $8.05 \pm 0.22^{\mathrm{e}}$ & $49.00 \pm 1.29^{\mathrm{de}}$ \\
\hline \multirow[t]{3}{*}{ TDZ $(0.5 \mathrm{mg} / \mathrm{l})$} & $\mathrm{P}$ & $6.00 \pm 0.40^{\mathrm{c}}$ & $4.85 \pm 0.12^{\mathrm{ab}}$ & $52.50 \pm 1.25^{\mathrm{f}}$ \\
\hline & $1 / 2 \mathrm{MS}$ & $4.75 \pm 0.25^{\mathrm{b}}$ & $5.02 \pm 0.16^{\mathrm{b}}$ & $40.00 \pm 0.81^{\mathrm{b}}$ \\
\hline & $1 / 2 \mathrm{MS}+\mathrm{TDZ}(0.01)$ & $11.00 \pm 0.40^{\mathrm{e}}$ & $7.17 \pm 0.16^{\mathrm{d}}$ & $61.00 \pm 1.29^{\mathrm{g}}$ \\
\hline
\end{tabular}

Parameters have been recorded after 4 weeks of transfer in multiplication media. Data are in the form of mean \pm SEM, and means followed by the same letter within the columns are not significantly different $(P=0.05)$ using Duncan's multiple range test

Table 3 Effect of MS salt concentration and IBA on in vitro root induction

\begin{tabular}{clcl}
\hline Rooting media & IBA $(\mathrm{mg} / \mathrm{l})$ & Number of roots & Root length $(\mathrm{cm})$ \\
\hline $1 / 2$ MS media & 0.2 & $1.75 \pm 0.25^{\mathrm{a}}$ & $1.85 \pm 0.09^{\mathrm{a}}$ \\
& 0.5 & $3.25 \pm 0.25^{\mathrm{b}}$ & $1.87 \pm 0.11^{\mathrm{a}}$ \\
& 1.0 & $6.00 \pm 0.40^{\mathrm{c}}$ & $2.20 \pm 0.18^{\mathrm{a}}$ \\
$1 / 4$ MS media & 0.2 & $2.75 \pm 0.25^{\mathrm{ab}}$ & $2.12 \pm 0.11^{\mathrm{a}}$ \\
& 0.5 & $6.25 \pm 0.85^{\mathrm{c}}$ & $2.80 \pm 0.18^{\mathrm{b}}$ \\
& 1.0 & $11.00 \pm 0.40^{\mathrm{d}}$ & $4.62 \pm 0.19^{\mathrm{c}}$ \\
\hline
\end{tabular}

Parameters have been recorded after 4 weeks of transfer in rooting media. Data are in the form of mean \pm SEM, and means followed by the same letter within the columns are not significantly different $(P=0.05)$ using Duncan's multiple range test

shoots $3.42 \pm 0.39$ ) and $0.5 \mathrm{mg} / \mathrm{l} \mathrm{BAP}+0.5 \mathrm{mg} / \mathrm{l} \mathrm{Kn}$ (average shoot length $7.54 \pm 0.31 \mathrm{~cm})$. BAP $(0.2 \mathrm{mg} / 1$ alone) and BAP/Kn $(0.5 \mathrm{mg} / \mathrm{l}$ each) showed same result in terms of number of shoots, but considering all the parameters together, BAP $(0.2 \mathrm{mg} / \mathrm{l})$ produced the best response in shoot induction media (Table 1).

Nodal explants inoculated on half strength MS media having concentration of TDZ $(0.01,0.03,0.05,0.1,0.2$, $0.5 \mathrm{mg} / \mathrm{l}$ ) showed shoot development at every concentration (Fig. 1a); $0.5 \mathrm{mg} / \mathrm{l}$ was found to be the most effective, i.e., number of shoots $(3.00 \pm 0.57)$, shoot length $(2.20 \pm 0.11 \mathrm{~cm})$ and number of leaves $(33.00 \pm 2.88)$ (Table 1). It was noted that at lower concentration of TDZ, number of shoots was less and shoot length high, and on increasing the concentration, multiple shooting increases, but with decreased shoot length. Mithila et al. (2003) reported that low concentration of TDZ induced shoot organogenesis of African violet explants, whereas at higher doses $(5-10 \mu \mathrm{M})$ somatic embryos were formed. Among other agents with cytokinin activity, comparatively low amount of TDZ promotes shoot multiplication in several plants (Guo et al. 2011). It was also reported that TDZ induced better response than BA (6-benzyl adenine) in shoot regeneration in peanut (Victor et al. 1999; Gairi and Rashid, 2004). Role of TDZ in shoot induction and multiple shooting has been reported in other plants as well; the highest rate of shoot regeneration from Echinacea purpurea leaf explants cultured on medium with TDZ at $2.5 \mu \mathrm{M}$ or higher was reported (Jones et al. 2007). TDZ, a phenylurea type plant growth regulator, was earlier used as a cotton defoliant (Arndt et al. 1976). Later, it was believed to exhibit strong cytokinin-like activity almost similar to that of N6-substituted adenine derivatives (Mok et al. 1982; Gyulai et al. 1995). In the present study, TDZ appears to mimic cytokinin-like activity causing the release of lateral buds (Wang et al. 1986) and showed better response in terms of shoot regeneration efficiency, compared to other cytokinins, similar to other findings where TDZ produced shoots comparable to or greater than that of other cytokinins (Fiola et al. 1990; Malik and Saxena 1992).

At initial stage, best response of shoot induction, considering all the parameters together was observed at BAP $(0.2 \mathrm{mg} / \mathrm{l}), \mathrm{Kn}(0.2 \mathrm{mg} / \mathrm{l}), \mathrm{BAP} / \mathrm{Kn}(0.2 \mathrm{mg} / \mathrm{l} \mathrm{each})$ and TDZ $(0.5 \mathrm{mg} / \mathrm{l})$ (Table 1). These best concentrations, respectively, denoted as B, E, H and P were selected and transferred to different shoot multiplication media (Table 2).

\section{Shoot multiplication}

Shoots cultured in the same induction medium B, E, H, P and half MS medium devoid of growth regulator (Fig. 1b) produced minimal response of shoot multiplication; 

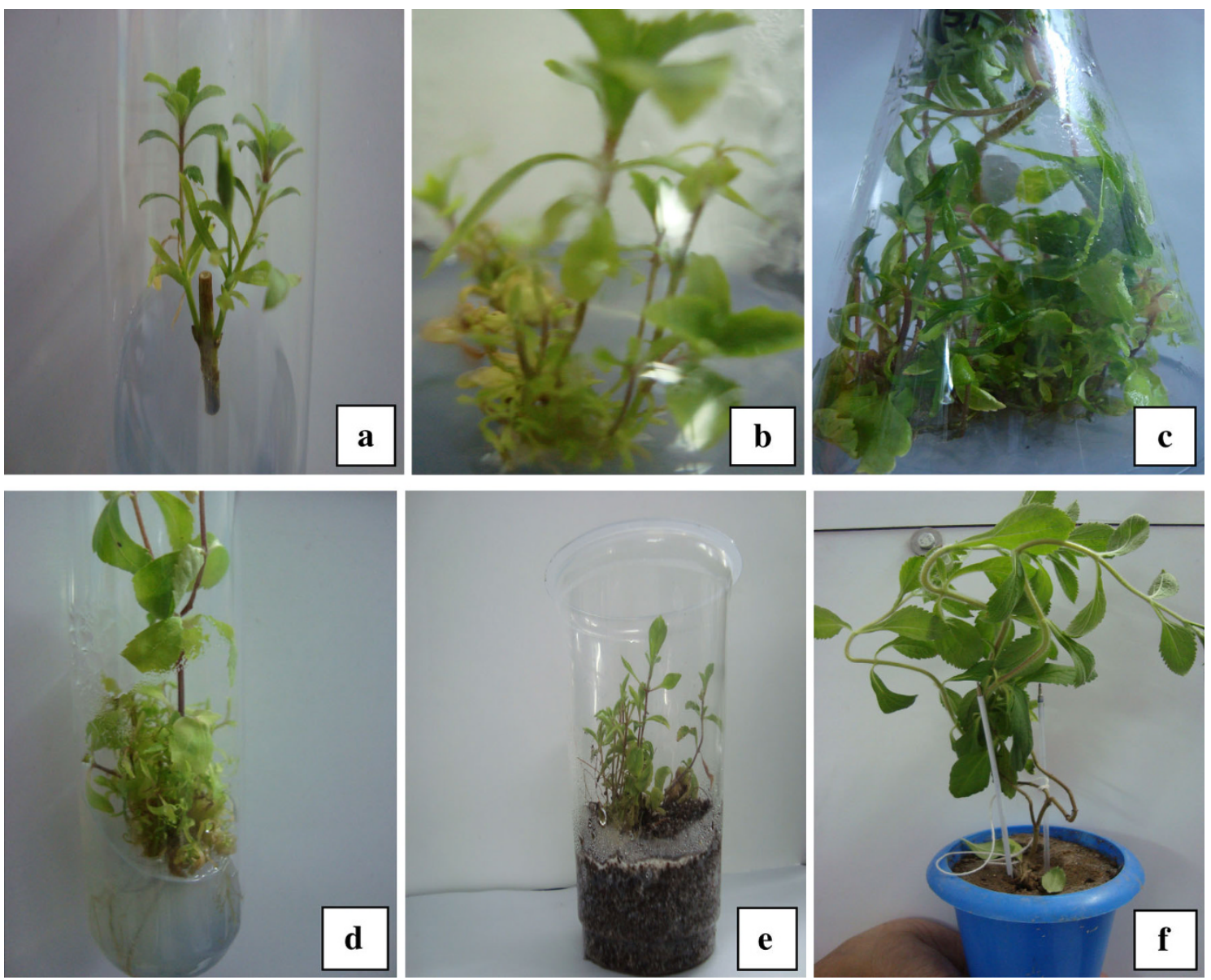

Fig. 1 In vitro shoot multiplication and rooting of Stevia rebaudiana. a Shoot formation in $1 / 2$ MS supplemented with $0.01 \mathrm{mg} / \mathrm{l} \mathrm{TDZ}$. b Cultures in induction media TDZ $(0.5 \mathrm{mg} / \mathrm{l})$ transferred to $1 / 2 \mathrm{MS}$ multiplication media without hormone. c Cultures in induction media

however, those sub-cultured in the half MS multiplication medium containing TDZ produced significantly higher number of shoots (Fig. 1c), the best response being observed in TDZ $(0.01 \mathrm{mg} / \mathrm{l})$. Shoots obtained from induction medium $\mathrm{P}$ containing TDZ $(0.5 \mathrm{mg} / \mathrm{l})$ produced highest number of shoots $(11.00 \pm 0.40)$ in half MS multiplication media containing $0.01 \mathrm{mg} / \mathrm{l} \mathrm{TDZ}$ (Table 2). However, shoot obtained from the induction medium B containing BAP $(0.2 \mathrm{mg} / \mathrm{l})$, E containing $\mathrm{Kn}(0.2 \mathrm{mg} / \mathrm{l})$ and $\mathrm{H}$ containing $\mathrm{BAP} / \mathrm{Kn} \quad(0.2 \mathrm{mg} / \mathrm{l}$ each $)$, produced $(9.25 \pm 0.25), \quad(8.50 \pm 0.28), \quad(8.75 \pm 0.25) \quad$ shoots, respectively, when transferred separately in MS half containing $0.01 \mathrm{mg} / \mathrm{l} \mathrm{TDZ}$. The number of shoots obtained is lesser when compared with those obtained from medium $\mathrm{P}$ containing $0.5 \mathrm{mg} / \mathrm{l} \mathrm{TDZ}$ (Table 2).

Shoot elongation

Shoot length increased in all the media supplemented with TDZ (Fig. 1c). Shoot obtained from induction medium $\mathrm{H}$
TDZ $(0.5 \mathrm{mg} / \mathrm{l})$ transferred to $1 / 2 \mathrm{MS}$ multiplication media supplemented with TDZ $(0.01 \mathrm{mg} / \mathrm{l})$. d In vitro rooting in $1 / 4 \mathrm{MS}$ supplemented with IBA. e Hardened plants in perlite. f In vitroraised Stevia rebaudiana in garden soil and sand mixture

(BAP/Kn $0.2 \mathrm{mg} / \mathrm{l}$ each) showed highest shoot length $(8.05 \pm 0.22)$ when transferred in half MS multiplication medium supplemented with $0.01 \mathrm{mg} / \mathrm{l} \mathrm{TDZ}$ (Table 2). It is to be noticed that there is a minute difference in shoot length of cultures obtained from induction medium $\mathrm{H}$ (BAP/Kn $0.2 \mathrm{mg} / \mathrm{l}$ each) and P (TDZ $0.5 \mathrm{mg} / \mathrm{l}$ ), when they were transferred separately in half MS medium supplemented with $0.01 \mathrm{mg} / \mathrm{lDZ}$. The shoots sub-cultured in the same induction medium $(\mathrm{B}, \mathrm{E}, \mathrm{H}, \mathrm{P})$ and half MS medium devoid of growth regulator (Fig. 1b) did not significantly increase the length of the shoots (Table 2). Also, it is observed that shoot cultured in the medium containing TDZ produced significantly more number of leaves (Fig. 1c). Highest number of leaves $(61.00 \pm 1.29)$ was observed in the multiplication media with $1 / 2$ MS + TDZ $(0.01 \mathrm{mg} / \mathrm{l})$, the shoots when cultured in the same induction medium (B, E, H, P) and half MS medium devoid of growth hormone showed comparatively lesser number of leaves, i.e., in the range of 30-52 leaves (Table 2). 
Root induction and hardening

Elongated shoots were separated from the shoot multiplication media and transferred to the rooting media. Root induction was observed in all cultures supplemented with different concentrations of IBA (Fig. 1d). IBA added to one-fourth MS medium produced a better rooting response as compared to half MS (Table 3). Highest number of roots (11.00) with longer roots $(4.62 \mathrm{~cm})$ was obtained on onefourth MS medium supplemented with $1.0 \mathrm{mg} / \mathrm{l}$ IBA (Table 3 ). Use of activated charcoal in the rooting media facilitated rooting, as also reported in other studies (Komalivalli and Rao 2000; Priyadarshini et al. 2007). Rooted plants were hardened in perlite (Fig. 1e) where all of them were healthy and viable for 3 weeks in the culture room. The survival rate of the transferred rooted plants into the pots containing garden soil and sand (1:1) was $80 \%$, after 2 months (Fig. 1f). Two-stage culture procedure seems to be a versatile protocol for efficient induction and multiple shoot formation, in Stevia similar to that noticed in Cassia angustifolia (Iram and Anis 2007) and Pterocarpus marsupium (Husain et al. 2007). A two-stage culture procedure has been developed for highly efficient shoot regeneration from leaf and internode explants of Bacopa monnieri (Ceasar et al. 2010).

\section{Stevioside content}

The presence of the active principles was confirmed in both the in vivo- and in vitro-derived leaves of Stevia. The identification and quantification of stevioside content in the samples were done by comparing the retention time and peak area of sample with that of the standard. In samples of in vitro plants, HPLC analysis revealed that stevioside content was higher than those of in vivo plants. Initial study showed that stevioside production was tissue and age dependent (data not shown). The percentage stevioside

Table 4 Stevioside content in in vivo and in vitro leaf samples

\begin{tabular}{|c|c|c|c|c|c|}
\hline $\begin{array}{l}\text { S. } \\
\text { no. }\end{array}$ & Samples & Medium & $\begin{array}{l}\text { Retention } \\
\text { time } \\
\text { (mm:ss) }\end{array}$ & $\begin{array}{l}\text { Peak } \\
\text { area } \\
(\mathrm{mAs})\end{array}$ & $\begin{array}{l}\text { Stevioside } \\
\text { content }(\%)\end{array}$ \\
\hline 1 & Standard & - & $2: 22$ & 596.1 & - \\
\hline 2 & In vivo plants & - & $2: 21$ & $8,421.6$ & $7.017 \pm 0.058$ \\
\hline 3 & $\begin{array}{l}\text { In vitro } \\
\text { plants (3- } \\
\text { week-old) }\end{array}$ & $\begin{array}{l}\text { Half } \\
\text { strength } \\
\text { MS }\end{array}$ & $2: 24$ & $11,040.7$ & $9.236 \pm 0.046$ \\
\hline 4 & $\begin{array}{l}\text { In vitro- } \\
\text { raised } \\
\text { plants (8- } \\
\text { week-old) }\end{array}$ & $\begin{array}{l}\text { Half } \\
\text { strength } \\
\text { MS }\end{array}$ & $2: 24$ & $11,040.7$ & $9.236 \pm 0.046$ \\
\hline
\end{tabular}

Two replicates of each sample were used for HPLC analysis (mean value calculated) content of the samples, in the in vivo and in vitro leaves of Stevia was found to be $7.017 \pm 0.058$ and $9.236 \pm 0.046$, respectively (Table 4 ); the in vitro-raised plants had higher stevioside content.

In conclusion, the present study demonstrates an efficient micropropagation protocol of $S$. rebaudiana using two-stage culture procedures. Furthermore, the micropropagation protocol generated did not affect the content of stevioside in Stevia leaves as shown by its higher content in the in vitro-raised leaves. The protocol might be useful in germplasm conservation and stevioside production.

Acknowledgments The authors are thankful to the University Grants Commission (UGC), New Delhi for the financial assistance in the form of a major research project.

Conflict of interest We declare that we do not have any conflict of interest in the publication. Further, we state that this manuscript is original, unpublished and not under simultaneous consideration by another journal.

Open Access This article is distributed under the terms of the Creative Commons Attribution License which permits any use, distribution, and reproduction in any medium, provided the original author(s) and the source are credited.

\section{References}

Ahmed MB, Salahin M, Karim R, Razvy MA, Hannan MM, Sultana R, Hossain M, Islam R (2007) An efficient method for in vitro clonal propagation of newly introduced sweetener from plant Stevia rebaudiana Bertoni in Bangladesh. Am-Eurasian J Sci Res 2(2):121-125

Alhady MRAA (2011) Micropropagation of Stevia rebaudiana Bertoni-a new sweetening crop in Egypt. Glob J Biotechnol Biochem 6(4):178-182

Ali A, Gull I, Naz S, Afghan S (2010) Biochemical investigation during different stages of in vitro propagation of Stevia rebaudiana. Pak J Bot 42(4):2827-2837

Anbazhagan M, Kalpana M, Rajendran R, Natarajan V, Dhanavel D (2010) In vitro production of Stevia rebaudiana Bertoni. Emir J Food Agric 22(3):216-222

Arndt F, Rusch R, Stillfried HV (1976) SN 49537, a new cotton defoliant. Plant Physiol 57:99

Ceasar SA, Maxwell SL, Prasad KB, Karthigan M, Ignacimuthu S (2010) Highly efficient shoot regeneration of Bacopa monnieri (L.) using a two-stage culture procedure and assessment of genetic integrity of micropropagated plants by RAPD. Acta Physiol Plant 32:443-452

Das A, Gantait S, Mandal N (2011) Micropropagation of an elite medicinal plant: Stevia rebaudiana Bert. Int J Agric Res 6:40-48

Duncan DB (1955) Multiple range and multiple $F$-tests. Biometrics $11: 1-42$

Fiola JA, Hassan MA, Swartz HJ, Bors RH, McNicols R (1990) Effect of thidiazuron, light fluence rates and kanamycin on in vitro shoot organogenesis from excised Rubus cotyledons and leaves. Plant Cell Tissue Org Cult 20:223-228

Gairi A, Rashid A (2004) Direct differentiation of somatic embryos on different regions of intact seedlings of Azadirachta in response to thidiazuron. J Plant Physiol 161:1073-1077 
Geuns JMC (2003) Molecules of interest: Stevioside. Phytochemistry 64:913-921

Guo B, Abbasi BH, Zeb A, Xu LL, Wei YH (2011) Thidiazuron: a multi-dimensional plant growth regulator. Afr J Biotechnol 10(45):8984-9000

Gyulai G, Jekkel Z, Kiss J, Heszky LE (1995) A selective auxin and cytokinin bioassay based on root and shoot formation in vitro. J Plant Physiol 145:379-382

Husain MK, Avis M, Shahzad A (2007) In vitro propagation of Indian kino (Pterocarpus marsupium Roxb.) using thidiazuron. In Vitro Cell Dev Biol Plant 43:59-64

Iram S, Anis M (2007) In vitro shoot multiplication and plantlet regeneration from nodal explants of Cassia angustifolia Vahl. a medicinal plant. Acta Phys Plant 29:233-238

JECFA (2007) Prepared at the 68th JECFA (2007) and published in FAO JECFA Monographs 4 (2007), superseding tentative specifications prepared at the 63rd JECFA (2004), in the combined compendium of food additive specifications, FAO JECFA Monographs 1 (2005)

Jones MP, Yi Z, Murch SJ, Saxena PK (2007) Thidiazuron-induced regeneration of Echinacea purpurea L.: micropogation in solid and liquid culture systems. Plant Cell Rep 26:13-19

Komalivalli N, Rao MV (2000) In vitro micropropagation of $G$. sylvestre-a multipurpose medicinal plant. Plant Cell Tissue Org Cult 61:97-105

Malik KA, Saxena PK (1992) Regeneration of Phaseolus vulgaris L. High-frequency induction of direct shoot formation in intact seedlings by N6-benzylaminopurine and thidiazuron. Planta 186:384-389

Mehta J, Sain M, Sharma DR, Gehlot P, Sharma P, Dhaker JK (2012) Micropropagation of an anti diabetic plant-Stevia rebaudiana Bertoni (natural sweetener) in Hadoti region of south-east Rajasthan, India. ISCA J Biol Sci 1(3):37-42

Mithila J, Hall JC, Victor JMR, Saxena PK (2003) Thidiazuron induces shoot organogenesis at low concentrations and somatic embryogenesis at high concentrations on leaf and petiole explants of African violet (Saintpaulia ionantha Wendl.). Plant Cell Rep 21(5):408-414

Mitra A, Pal A (2007) In vitro regeneration of Stevia rebaudiana Bert. from the nodal explants. J Plant Biochem Biotechnol 16:59-62
Mok MC, Mok DWS, Armstrong DJ, Shudo K, Isogai Y, Okamoto T (1982) Cytokinin activity of $N$-phenyl- $N$-1,2,3-thiadiazol-5-ylurea (thidiazuron). Phytochemistry 21:1509-1511

Murashige T, Skoog F (1962) A revised medium for rapid growth and bioassays with tobacco tissue cultures. Physiol Plant 15:473-497

Pande SS, Gupta P (2013) Plant tissue culture of Stevia rebaudiana (Bertoni): a review. J Pharmacogn Phytother 5(1):26-33

Priyadarshini GR, Kumar A, Janifer X (2007) Micropropagation studies in Stevia rebaudiana Bertoni. In: Kukreja AK, Mathur AK, Banerjee S, Mathur A, Sharma A, Khanuja SPS (eds) Proceedings of national symposium on plant biotechnology: new frontiers. CIMAP, Lucknow, pp 121-127

Ranganathan J (2012) Studies on micropropagation of Stevia rebaudiana. Int J Pharmacol Biol Arch 3(2):315-320

Sairkar P, Chandravanshi MK, Shukla NK, Mehrotra MN (2009) Mass propagation of an economically important medicinal plant Stevia rebaudiana using in vitro propagation technique. $\mathrm{J}$ Med Plants Res 3(4):266-270

Singh SD, Rao GP (2005) Stevia: the herbal sugar of 21st century. Sugar Technol 7:17-24

Singh P, Dwivedi P, Atri N (2012) In vitro shoot regeneration of Stevia rebaudiana through callus and nodal segments. Int J Agric Environ Biotechnol 5(2):101-108

Sivaram L, Mukundan U (2003) In vitro culture studies on Stevia rebaudiana. In Vitro Cell Dev Biol Plant 39:520-523

Thiyagarajan M, Venkatachalam P (2012) Large scale in vitro propagation of Stevia rebaudiana Bert. for commercial application: pharmaceutically important and antidiabetic medicinal herb. Ind Crops Prod 37(1):111-117

Uddin MS, Chowdhury MS, Khan MM, Uddin MB, Ahmed R, Betan MA (2006) In vitro propagation of Stevia rebaudiana Bert in Bangladesh. Afr J Biotechnol 5:1238-1240

Victor JMR, Murthy BNS, Murch SJ, KrishnaRaj S, Saxena PK (1999) Role of endogenous purine metabolism in thidiazuroninduced somatic embryogenesis of peanut (Arachis hypogaea). Plant Growth Regul 28:41-47

Wang SY, Steffens GL, Faust M (1986) Breaking bud dormancy in apple with a plant bioregulator, thidiazuron. Phytochemistry $25: 311-317$ 